\title{
Authoritarian and Democratic Diffusion in Post-Communist Regions
}

\section{Tomila Lankina', Alexander Libman ${ }^{2,3}$, and Anastassia Obydenkova ${ }^{4}$}

\begin{abstract}
There is a rich body of theorizing on the diffusion of democracy across space and time. There is also an emerging scholarship on authoritarian diffusion. The dynamics of the interaction between external democratic and autocratic diffusion processes and their effects on national and sub-national political regime outcomes have received scant attention in the literature. Do democratic diffusion processes help counter external authoritarian influences? And, in contexts where external diffusion of democratic influences is weak, do we observe greater susceptibility to diffusion from regional autocracies that might in turn reinforce authoritarian practices and institutions in "recipient" states? To address these questions, we perform analysis of data from two original under-utilized data sets-a data set on the European Union (EU) aid to Russia's regions and a data set with statistics on trade among post-Soviet states. We find that EU aid has the effect of countering external authoritarian influences that work through Soviet-era inter-regional economic ties.
\end{abstract}

\footnotetext{
'London School of Economics \& Political Science, UK

${ }^{2}$ German Institute for International and Security Affairs, Berlin, Germany

International Center for the Study of Institutions and Development, National Research

University Higher School of Economics, Moscow, Russia

${ }^{4}$ Harvard University, Cambridge, MA, USA
}

\section{Corresponding Author:}

Tomila Lankina, International Relations Department, London School of Economics \& Political Science, Houghton Street, London WC2A 2AE, UK.

Email: t.lankina@Ise.ac.uk 


\section{Keywords}

Russia, post-Soviet states, sub-national, democratic diffusion, authoritarian diffusion, EU aid, trade with autocracies, democracy

\section{Introduction}

What are the transnational mechanisms of the development and reproduction of authoritarian regimes? There is a rich body of theorizing on the diffusion of democratic norms, institutions, and practices across space and time, arguably accounting for the pronounced patterns of clustering of regime types in Europe and Eurasia (Brinks \& Coppedge, 2006; Kopstein \& Reilly, 2000; Lankina \& Getachew, 2006; O'Loughlin et al., 1998). By contrast, scholarship on the mechanisms of authoritarian diffusion is in its infancy. A small number of studies have recently called attention to external aspects of autocratic diffusion, which may shape or reinforce regional constellations of regime types (Ambrosio, 2010; Cameron \& Orenstein, 2012; Koesel \& Bunce, 2013; Obydenkova \& Libman, 2015c; Plantan, 2014). The dynamics of the interaction between external democratic and autocratic diffusion processes and their effects on national and sub-national political regime outcomes have received scant attention in this emerging body of scholarship. Do democratic diffusion processes help limit and counter external authoritarian influences? And, in contexts where external diffusion of democratic influences is weak, do we observe greater susceptibility to diffusion from regional autocracies that might reinforce authoritarian practices and institutions in "recipient" states? To address these questions, we perform analysis of data from two original under-utilized data sets - a comprehensive data set on European Union (EU) aid to Russia's regions and a data set with statistics on regional trade, socio-economic indices, and democracy variations.

We find that not only does EU aid enhance regional democracy, as had been previously demonstrated (Lankina \& Getachew, 2006, 2008; Obydenkova, $2008,2012)$, but also, and most importantly for this article, it has the effect of countering external autocratic influences that work through Soviet-era interregional economic ties. We find that regions featuring extensive economic ties with neighboring post-Soviet autocracies are more likely to score lower on assessments of the quality of regional democracy. We also find however that EU aid serves to mitigate these autocratic influences. Regions that have been relatively insulated from EU attempts to shape regional politics are likely to score lower on democracy ratings as compared with those that in the 1990s and 2000s have been recipients of comparatively large volumes of EU aid.

In terms of the channels of the transmission of democratic and autocratic influences, we find that civil society is an important conduit for democratic 
influences: EU aid to non-governmental organizations helps promote regional political pluralism and establish checks on regional regimes. Conversely, Soviet-era trade and industrial ties between Russian regions and post-Soviet neighboring autocracies appear to reproduce Soviet-era political-economic networks and power structures, which may be corrosive to democracy. These patterns of autocratic diffusion-through-trade may in turn help reinforce and reproduce patterns of authoritarian clustering in the region. Importantly, the article finds that EU aid significantly mitigates the negative regime effects of economic ties with autocracies.

Our article is structured as follows. In the next section, we discuss the theoretical and empirical literature on democratic and authoritarian diffusion. Next, we describe our data and methods and present results of statistical analysis. The final section concludes with a discussion of the implications of our findings for understanding the contending processes of authoritarian and democratic diffusion in Europe and Eurasia.

\section{Theorizing External Democratic and Authoritarian Diffusion}

The emergence of pronounced spatial variations in political regime types in post-Communist Europe has spurred rich theorizing on democratic diffusion processes (Beissinger, 2007; Brinks \& Coppedge, 2006; Elkins \& Simmons, 2005; Fordham \& Asal, 2007; Gleditsch \& Ward, 2006; Kopstein \& Reilly, 2000; Lankina \& Getachew, 2006; O'Loughlin et al., 1998; Obydenkova \& Libman, 2014, 2015a, 2015b). Democratic diffusion studies provided an important corrective to scholarship that sought to explain emerging variations in post-communist democratic trajectories with reference to variables largely divorced from the geographic-spatial contexts in which particular states, regions, or localities were embedded.

The mammoth presence of the EU as the neighborhood's most important normative power inevitably conditioned scholars to focus on democratic forms of diffusion (Bunce \& Wolchik, 2011; Dimitrova \& Pridham, 2004; Kopstein \& Reilly, 2000; Lankina, Hudalla, \& Wollmann, 2008; Levitsky \& Way, 2010; Pridham, 1994; Schimmelfennig, 2002; Schimmelfennig \& Sedelmeier, 2005; Vachudova, 2005; Whitehead, 2001; Zielonka \& Pravda, 2001). A mere glance at the political map of Europe suffices to note that space and geographic proximity did matter for extending carrots in the form of prospective EU membership. Scholars have noted that the policy of incentivizing the development of democratic institutions and practices (Kelley, 2006) has been manifested also in instruments such as the European Neighborhood Policy designed to engage eastern neighbors - and the sub-national regions 
within neighboring states (Gel'man \& Lankina, 2008; Lankina, 2005; Lankina \& Getachew, 2006, 2008; Obydenkova, 2008, 2012)—without actually "letting them in," at least in the short term (Kelley, 2006; Korosteleva, Natorski, \& Simão, 2013; Langbein \& Börzel, 2013; Smith, 2005). These forms of planned and deliberate EU assistance have been variously conceptualized in terms of leverage, conditionality, and targeted democracy promotion.

A number of studies have shown that geography matters not only for the choice to extend the above forms of EU engagement in its neighborhood but also in terms of the intensity of the more spontaneous forms of diffusion, as would be the case with citizen-to-citizen interactions, business exchanges, or cultural ties. These forms of diffusion happen "without any collaboration, imposition, or otherwise programmed effort on the part of any of the actors" (Elkins \& Simmons, 2005, p. 6, cited in Ambrosio, 2010); they have been conceptualized in terms of flows (Kopstein \& Reilly, 2000), socialization (Kelley, 2006), or linkage (Levitsky \& Way, 2006, 2010).

An emerging body of scholarship has problematized the scholarly preoccupation with democratic forms of diffusion in Europe - targeted or spontaneous - suggesting that similar insights could be applied to explain spatial patterns of clustering of Europe's authoritarian regimes or states in the gray area between democracies and full-blown autocracies. As Thomas Ambrosio notes, “. . . international pull toward democratization is only half-understood because it does not account for a countervailing pull from authoritarian regimes" (Ambrosio, 2007, p. 236). Emerging scholarship on authoritarian diffusion has focused on both the more "spontaneous" forms of autocratic influence, as would be the case with diffusion through trade (Libman \& Obydenkova, 2014; Obydenkova \& Libman, 2012, 2015b), and on the more targeted regime strategies to "resist" (Koesel \& Bunce, 2013) what are presented as Western attempts to foment regime change or regional instability under the guise of democracy promotion (Ademmer \& Börzel, 2013; Allen \& Gershman, 2006; Ambrosio, 2007, 2010; Brunell, 2006; Carothers, 2006; Diamond, 2008; Finkel \& Brudny, 2012a; Koesel \& Bunce, 2013; Plantan, 2014; Silitski, 2009, 2010; Walker \& Kelly, 2007; Way, 2010; Wilson, 2009; Wilson \& Popescu, 2009).

The above literature on authoritarian diffusion is a welcome departure from earlier scholarship premised on teleological notions of a steady march of democracy from the West to the East. Yet, this literature, eager as it is to problematize the notion of democratic diffusion, has likewise suffered from a one-sided preoccupation with spatial dynamics of the spread and consolidation of authoritarianism (but see Ambrosio, 2010; Wilson \& Popescu, 2009). Furthermore, the theoretical and empirical treatments of authoritarian 
diffusion in Europe and Eurasia have overwhelmingly focused on just two autocracies - Russia and China - as active agents of authoritarian diffusion or democratic resistance (Allison, 2013; Finkel \& Brudny, 2012b; Koesel \& Bunce, 2013; Plantan, 2014; Silitski, 2009; Wilson, 2009; Wilson \& Popescu, 2009). Authoritarian diffusion is seen as a one-way process (but see Gel'man \& Lankina, 2008), whereby the more powerful autocrats such as Russia or China undermine democracy or reinforce authoritarian practices through exercising economic or other forms of leverage in weaker neighborhood states, or simply by having a "prestige" effect whereby lesser powers are likely to emulate their policies, institutions, and practices (Ambrosio, 2008; Cameron \& Orenstein, 2012; Fordham \& Asal, 2007; Wilson \& Popescu, 2009). Yet, a near-exclusive focus on Russia or China as regional authoritarian states shaping patterns of authoritarian diffusion obscures the importance of lesser autocracies. The latter may not have fashioned targeted strategies of authoritarian diffusion, but may be nonetheless reinforcing authoritarian trends in neighboring states and regions via more spontaneous forms of diffusion or through socialization in sub-regional institutional and political alliances (Allison, 2008; Collins, 2009; Darden, 2010).

Any analysis of external democratic and authoritarian diffusion processes would be of course also incomplete without factoring in the domestic influences on the spread of authoritarian tendencies, or, alternatively, democratic resilience within particular states. A large body of scholarship on Russia has precisely explored such within-nation processes by comparing political regime development in Russia's sub-national regions (Gel'man \& Ross, 2010; Gel'man, Ryzhenkov, Brie, Ovchinnikov, \& Semenov, 2003; Hale, 2006; Lankina, Libman, \& Obydenkova, 2016; McFaul, Petrov, \& Riabov, 2004; McMann, 2006; Stoner-Weiss, 1997). For instance, in-depth research has been conducted into how the Kremlin under Putin's rule undermined sub-national proto-democratic institutions and electoral competition (Golosov, 2011; Panov \& Ross, 2013; Reddaway \& Orttung, 2005b; Reuter \& Remington, 2009), and how it has tended to reward regional elites for delivering a pro-Kremlin vote rather than for good governance or economic performance (Reuter \& Buckley, 2015; Reuter \& Robertson, 2012; Rochlitz, 2014). Scholars have also analyzed how regional authorities tend to emulate the practices of neighboring regions in ways that may further erode democratic institutions (Gel'man \& Lankina, 2008; Moraski \& Reisinger, 2014). We concur that longer term structural variations and the more contingent factors such as center-regional elite and party-political dynamics have an important bearing on political regime variations in Russia's regions. In our statistical analysis, we seek to capture the effect of key variables conventionally employed in research into domestic influences on regional democratic variations. Yet, we also demonstrate that 
additional - external - drivers of sub-national authoritarianism and democratic diffusion are at work.

We do so by empirically addressing a number of pertinent research questions. The first question is about the effect of interaction between authoritarian and democratic diffusion on regime outcomes in "recipient" states. The second question is whether authoritarian diffusion transcends major regional powers and may be also characteristic of lesser regional players like Central Asian states or Azerbaijan. The third question relates to the potential of EU democratic diffusion in Eastern Neighborhood states unlikely to become EU members in the foreseeable future to counteract authoritarian diffusion processes in Europe. Finally, the fourth question relates to the channels through which the respective actors might influence democratic variations in "recipient" states or regions.

Our study begins to address these theoretically important and policy-relevant questions. We utilize a comprehensive data set of EU projects carried out in Russia's regions assembled by Tomila Lankina (The Lankina EU Aid Dataset). The total number of projects in the data set is more than 1,000. To our knowledge, this remains the only source of systematic data on the subnational component of EU aid to post-Soviet states. The data cover the years 1990 to 2003, and contain vast amount of detail on funding amounts, project aims and objectives, the key European partner involved in the project, the key implementing local partner on the ground, whether the Russian federal government had been involved in the project, and any other foreign and other local partners involved. The data set allows to obtain a detailed picture of the EU's strategic aims and objectives in states with limited membership prospects, what types of projects it actually ends up carrying out, what kinds of partners and regions it tends to reward, and the spatial dimension of this aid activity.

The nature of the projects and their stated aims vary, ranging from projects to support the modernization of regional bureaucracies, to support for ethnic minority group song-and-dance ensembles, to funding to environmental awareness non-governmental organizations (NGOs), to sponsorship of crossborder cooperation initiatives involving local mayors and councilors. Consistent with earlier scholarship on the domestic effects of cooperation with democratic nations and supra-national actors (Pevehouse, 2002; Pevehouse \& Russett, 2006), we consider EU aid as a general proxy for the extent of socialization with EU counterparts that in turn promotes democratic values that the EU holds dear. Furthermore, in EU documents, even the more "technical" projects such as those aimed at raising bureaucratic competence in the regions tend to be framed in terms of the wider strategic objectives of advancing market economies and "pluralistic democratic societies." Implicit 
in this approach are ideas akin to those developed by Karl Deutsch several decades ago, in the context of post-World War II reconstruction. Deutsch saw contact and interactions - including social interactions - among Europeans as conducive to the development of trust and a core set of shared values (Deutsch, 1954). Because our data allow us to distinguish among project beneficiaries (for instance, regional officials, NGOs), we are able to gauge the extent of socialization in EU values of these distinct sets of regional actors. ${ }^{2}$

The cut-off point for our EU aid data, 2004, coincided with an important policy shift in EU's relations with eastern neighbors whereby Russia and EU renegotiated their relationship to pursue the so-called "four spaces." The year 2004 also marks the beginning of Russia's steady descent into authoritarianism and Vladimir Putin's imposition of a centralist architecture on Russia's federal polity (Lankina, 2009; Reddaway \& Orttung, 2005a). The implications of these changes in Russia's relations with the EU and in its federal architecture were greater centralization of domestic policy making and greater monitoring of activities of EU actors. By 2004 however, some regions will have experienced nearly 15 years of exposure to EU projects - some to a considerable extent - and the trappings that come from such exposure in the form of support for institutional development, training, equipment, knowhow, skills, interaction with European partners abroad, and frequent travels to European partner localities. Project activity thus likely captures both the targeted dimension of the diffusion of EU influences through aid and the more spontaneous aspects of democratic diffusion insofar as aid fosters the development of linkages among ordinary citizens.

No such comparable data exist for the targeted aspect of authoritarian diffusion in the Eurasian region. In any case, barring the relatively recent systematic attempts to project an authoritarian brand of soft power by regional autocracies such as Russia, few other post-Soviet states have pursued, or would be financially in a position to pursue, sustained efforts to influence democracy in neighboring countries equivalent to those of the EU. Even the powerful autocracies such as Russia and China are not concerned with aggressively propagating particular ideologies, but are more concerned with curbing democracy promotion that they see as a threat to their regime survival (Ambrosio, 2007). The channels of influence of these states on their neighbors are likely to be through a form of demonstration effect whereby actors that regularly interact with one another end up emulating the practices, modes of behavior, and value orientations of their counterparts in business, administrative bureaucracies, or the political sphere (Ambrosio, 2010; Cameron \& Orenstein, 2012). Recent studies have demonstrated the intensity of labor migration, trade links, and economic interdependence among postSoviet states (Cameron \& Orenstein, 2012; Lankina \& Niemczyk, 2015). 
Cameron and Orenstein (2012) note that the Russian market is crucial for national economies of all but three post-Soviet states, namely the global oiland gas-exporting states of Azerbaijan and Turkmenistan, as well as Georgia. For instance, $25 \%$ to $45 \%$ of exports of Belarus, Ukraine, and Moldova, and $8 \%$ to $25 \%$ of exports from Armenia, Kyrgyzstan, Latvia, and Lithuania are targeted at the Russian market. ${ }^{3}$ These trade dependencies have been explained with reference to Soviet-era patterns of industrial location and supply, whereby particular republics specialized on the production of industrial goods or commodities utilized by specific industries in other parts of the Soviet Union. The importance of such links has been poignantly demonstrated in the recent conflict between Russia and Ukraine following Ukraine's expressed desire to join the Association Agreement with EU and subsequent abstention from signing the agreement in November 2013. Aside from Russia's usual threats to raise prices for gas supplied to Ukraine, Russia also resorted to economic blackmail that affected, inter alia, trade in consumer goods such as confectionary and other food products. At the same time, in what is also a legacy of Soviet-era industrial networks, Russia has until recently relied on Ukraine to supply important parts for its military-industrial complex.

In the next, statistical analysis, section of the article, we employ the EU aid and post-Soviet trade data, to analyze the interaction between EU influences and those of post-Soviet neighboring states, on Russia's sub-national democratic variations.

Based on the above theoretical discussion, we articulate our hypotheses as follows:

\section{General Effects}

Hypothesis 1: Geographic proximity to autocracies will have a negative effect on democracy in Russia's regions.

Hypothesis 2: EU aid will have a positive effect on democracy in Russia's regions.

Hypothesis 3: Trade with the countries of the former Soviet Union (FSU) will have a negative effect on democracy in Russia's regions.

Hypothesis 4: EU aid will counteract the negative effect of FSU trade on regional democracy.

\section{Specific Channels of EU Influence on Regional Democracy}

Hypothesis 5: EU aid will positively affect regional democracy through its influence on regional authorities. 
Hypothesis 6: EU aid will positively affect regional democracy through its influence on municipal authorities.

Hypothesis 7: EU aid will positively affect regional democracy through its influence on civil society actors (NGOs).

\section{Statistical Analysis}

\section{Data and Measures}

For our dependent variable, regional democratic variations, we employ the index of regional democracy originally developed by Nikolay Petrov and Aleksey Titkov, who at the time the index was developed were scholars at the Moscow Carnegie Center (Petrov \& Titkov, 2013). ${ }^{4}$ The index is a composite measure of regional political regime variations that is both based on subjective expert assessments and systematic data on electoral competition that they refer to as "instrumental" measures and that are conventionally employed in studies of cross-national democratic variations (Lankina \& Getachew, 2012; Vanhanen, 2000). The "instrumental" criteria are measures such as effective number of candidates in governor elections, the share of votes obtained by the winning candidate in governor elections, the rate of governor turnover, and recorded instances of electoral misconduct. As Petrov and Titkov readily admit, considering the known issue of potential subjectivity and bias in expert assessments, it is important to combine both the "subjective" and the "instrumental" measures in generating the composite index. As a further check on the validity of their measure, they cross-validate the "subjective" assessments with the "instrumental" measures, obtaining significant correlations between scores based on the two types of assessments, which are particularly strong for some sub-indicators. ${ }^{5}$ In what provides further reassurances of the validity of the democracy measures employed in our analysis, there is a strong degree of correspondence between Petrov and Titkov's assessments and those of scholars who have relied on other measures of regional democratic variations. For instance, consistent with Petrov and Titkov's findings, in both the studies that use "objective" measures of electoral competition and in qualitative scholarship relying on more "subjective" assessments, the "ethnic" republics have tended to feature strongly as regions that tend to have low levels of political competition and that are particularly likely to falsify votes in regional and federal elections (Hale, 2007; Lukinova, Myagkov, \& Ordeshook, 2011; Myagkov, Ordeshook, \& Shakin, 2009; Saikkonen, 2015). ${ }^{6}$ Likewise, again, consistent with Petrov and Titkov's indices, among the "Russian" oblasti, some regions such as Samara, Nizhegorodskaia, and St. Petersburg have been described as having comparatively more democratic political regime features 
(Lankina \& Getachew, 2006; McMann, 2006; Remington, 2011; StonerWeiss, 1997).

The Petrov and Titkov score consists of 10 sub-indicators, each assessed on a 5-point scale. The individual components of the index are then summed up to obtain a composite score, with higher values of the score corresponding to higher levels of regional democracy. The index is constructed in a way that allows to capture both the procedural elements of democracy (such as electoral freedoms) and its substantive aspects (political pluralism); overall, the logic behind the choice of sub-indicators for the score corresponds to conceptions of liberal democracy (Bollen, 1993). ${ }^{7}$ The democracy measure that we employ is a moving average score covering the years 2000 to $2004 .^{8}$

We capture authoritarian diffusion by analyzing trade links between the regions of Russia and post-Soviet states. Specifically, we employ the share of trade (export and import) with former Soviet states (FSU) in the total trade turnover of Russia's regions. There are two reasons why trade could act as a mechanism of regime diffusion. First, trade relations are associated with learning - both across elites and societies. In Eurasia, international trade transactions frequently require active participation of public officials who help to overcome legal and administrative barriers and to ensure the credibility of potential local business partners. We, therefore, anticipate that more intensive trade ties lead to more intensive exchanges among elite members of a given Russian region and the FSU country this region trades with. Because of widespread informal contacts between the political elites of trading states and regions, regional elites are likely to adapt practices and norms prevalent in the non-democratic FSU states (Obydenkova \& Libman, 2012). Second, the heavily politicized nature of external trade in Eurasia provides regional incumbents with an additional tool of control over regional economies. By withdrawing their support, governors can effectively undermine business transactions between companies operating in their region and the partner FSU country. As a result, companies in regions in which trade with FSU states is important in economic terms, are more likely to be interested in obtaining support of the governors - and exchanging it for political loyalty. (On the importance of economic control for the survival of Russian sub-national autocracies, see McMann, 2006. $)^{9}$ Note that unlike EU assistance, which is often conditional on good democratic performance, the impact of FSU trade on political regimes in the regions of Russia is mostly unintentional. The way FSU countries conduct their foreign trade relations in Eurasia may thus have an indirect effect on strengthening autocracy in Russia's regions.

Trade data are obtained from Russia's official statistical compilations. In our analysis, FSU refers to countries formerly part of the Soviet Union, excluding the Baltic states of Latvia, Estonia, and Lithuania, which are now in the EU. 
Our analysis also excludes Belarus, which has a customs arrangement with Russia within the framework of the Russia-Belarus Union; thus, our analysis largely captures trade between Russia's regions and Central Asian (Kazakhstan, Kyrgyzstan, Tajikistan, Turkmenistan, Uzbekistan) and Caucasus states (Armenia, Azerbaijan, Georgia), as well as Ukraine. There is substantial variation in the share of Russia's regional trade with FSU countries - ranging literally from $0 \%$ to more than $60 \%$ of a given region's total trade turnover.

As our proxy for the EU's democratic diffusion effect, we employ the measure of total volume of EU aid provided to a particular region in millions of Euros in the period between 1991 and 2004. In our cross-sectional regressions, the FSU trade indicator is averaged over a 5-year period, whereas EU aid is aggregated for the period 1991 to 2004. Employing these measures allows us to evaluate the long-term implications of EU aid for countering post-Soviet authoritarian diffusion. Trade between Russia's regions and FSU states is grounded in long-term ties, sometimes stretching over decades. The inter-elite contacts, which, as noted above, play an important role in authoritarian diffusion, in many cases also go back to the Soviet era-indeed both the post-Soviet countries and Russia's sub-national regions in the period of our investigation often had members of the old Soviet nomenklatura at the helm of power. Thus, to exercise a moderating effect on the hypothetical authoritarian diffusion mechanism, the EU influence should be lasting and long term; short-term aid flows may be insufficient to substantially affect regional regime variations. In one of our robustness checks, we also employ the measure of cumulative EU aid for 2000 to 2004.

Aside from the main explanatory variables and their interaction terms, we also include a set of control variables capturing additional influences on politics in Russia's regions. In particular, we control for income per capita, urbanization, and education. Education is proxied by the share of regional population with university education, because in Russia secondary schooling covers virtually the entire population. These three covariates are employed based on the logic of classic modernization theorizing (Lipset, 1959). We also control for regional oil and gas extraction to account for the possibility of a "resource curse" effect, which might be salient given Russia's resourcedriven economy (Ross, 2001). Furthermore, we create a dummy variable for regions with the status of republics. The republics are regions with territorially concentrated ethnic minority populations, which traditionally enjoyed higher status in the Soviet Union's and in post-Soviet Russia's ethno-federal hierarchy. As noted by a number of scholars, the republics had been instrumental in creating powerful political machines ensuring the reproduction of communist era and early post-communist period regional structures of power and patronage (Golosov, 2011; Hale, 2007; Matsuzato, 2004). We also 
include a measure of the share of ethnic Russians in the regional population. This variable captures preference heterogeneity in Russia's regions. In addition, we employ the measure of geographical distance between the regional capital and the City of Moscow in kilometers. More distant regions may be more difficult to control for the federal center; this in turn might facilitate the reproduction of powerful regional political machines. ${ }^{10}$

Summary statistics for the above variables are reported in the Supplementary Appendix IV. We obtained the data for the socio-economic control variables from Russian official statistical compilations. The timevarying control variables are averaged over the period 2000 to 2004. Data for the regional share of ethnic Russians and education are obtained from the 2002 census. In the regressions, we include Russia's regions as our observations, with the exception of Chechnya, for which reliable data are unavailable for the period under investigation; and, regions with autonomous okrug status, that is, those that are constituent units of other regions for which data are also patchy. ${ }^{11}$ Therefore, our sample includes 79 regions.

\section{Main Results}

We start with a brief examination of the descriptive statistics for our data. ${ }^{12}$ Table 1 splits the sample into four groups according to the median of the FSU trade and EU assistance measures. We report the democracy score, FSU trade share, and EU assistance for each of the sub-samples. One can see that the group of regions with the highest democracy score is that where EU assistance had been above the median, whereas FSU trade share had been below the median. This group also includes regions such as Karelia and Perm, which have frequently been discussed as being comparatively democratic. The lowest democracy score, conversely, is observed among regions with highest FSU trade levels and the lowest EU assistance levels. The results are consistent with our hypothesis that democratic diffusion could mitigate authoritarian diffusion.

In the next step, we regress the variable of sub-national democracy in Russia's regions on the proxy of authoritarian diffusion, the variable of democratic diffusion from the EU, as well as the interaction term of these two variables. We thereby seek to ascertain whether the democratic diffusion variable is able to moderate the effect of authoritarian diffusion.

In Table 2, Model 1, we regress the democracy score on both of the baseline variables; Model 2 adds the interaction term. As expected, FSU trade has a negative and significant impact on democracy levels; EU aid has a positive and significant effect. The most interesting result is, however, obtained in Model 2: The interaction term is significant and positive. Thus, EU aid has the 
Table I. Democracy, FSU Trade, and EU Assistance.

\begin{tabular}{|c|c|c|}
\hline & $\begin{array}{l}\text { EU assistance below the } \\
\text { median }\end{array}$ & $\begin{array}{l}\text { EU assistance above the } \\
\text { median }\end{array}$ \\
\hline \multirow[t]{4}{*}{$\begin{array}{l}\text { FSU trade below } \\
\text { the median }\end{array}$} & $\begin{array}{l}\text { Average democracy score: } \\
27.1\end{array}$ & $\begin{array}{l}\text { Average democracy score: } \\
33.6\end{array}$ \\
\hline & Average FSU trade: $4.5 \%$ & Average FSU trade: $5.8 \%$ \\
\hline & $\begin{array}{l}\text { Average EU assistance: } € 0.13 \\
\text { million }\end{array}$ & $\begin{array}{l}\text { Average EU assistance: } \\
€ 20.43 \text { million }\end{array}$ \\
\hline & $\begin{array}{l}\text { Examples: Krasnodar, } \\
\text { Primorsky }\end{array}$ & Examples: Karelia, Perm \\
\hline \multirow[t]{4}{*}{$\begin{array}{l}\text { FSU trade above } \\
\text { the median }\end{array}$} & $\begin{array}{l}\text { Average democracy score: } \\
24.7\end{array}$ & $\begin{array}{l}\text { Average democracy score: } \\
30.8\end{array}$ \\
\hline & Average FSU trade: $31.3 \%$ & Average FSU trade: $32.7 \%$ \\
\hline & $\begin{array}{l}\text { Average EU assistance: } € 0.15 \\
\text { million }\end{array}$ & $\begin{array}{l}\text { Average EU assistance: } \\
€ \text { II } .50 \text { million }\end{array}$ \\
\hline & Examples: Dagestan, Stavropol & Examples: Ivanovo, Rostov \\
\hline
\end{tabular}

FSU = former Soviet Union; EU = European Union.

effect of undermining the negative effects of FSU trade. When we plot the marginal effect of FSU trade on regional democracy for various values of EU aid, the results become even more pronounced (Figure 1). For low values of EU aid, FSU trade has a strong and negative impact on democracy. It does decrease in absolute value if EU aid goes up and eventually becomes insignificant (the zero is within confidence intervals). The insignificant effect, however, is observed for relatively few regions with very large volumes of EU aid: the cities of Moscow and St. Petersburg, Republic of Karelia, as well as the Kemerovo, Nizhny Novgorod, Novosibirsk, and Sverdlovsk oblasti. The figure also suggests that - hypothetically - for extremely high EU aid values, FSU trade would have a significant and positive effect on the democracy score. However, there are no regions in our sample for which EU aid is large enough to make the marginal effect of FSU trade positive and significant: Even for the region with the highest EU aid volumes, the effect of FSU trade is still insignificant. Thus, for the actual sample that we employ, the positive effect of FSU trade on democracy is never observed; for most regions, EU aid appears to have the effect of merely decreasing the negative democratic effects of FSU trade, but short of rendering it entirely insignificant.

Models 3 to 5 provide a number of important robustness checks. The rationales for these tests are as follows. First, it is possible that the effect of aid on political regimes depends not only on the trade partner but also on the industrial structure of trade, which could influence the likelihood and importance 


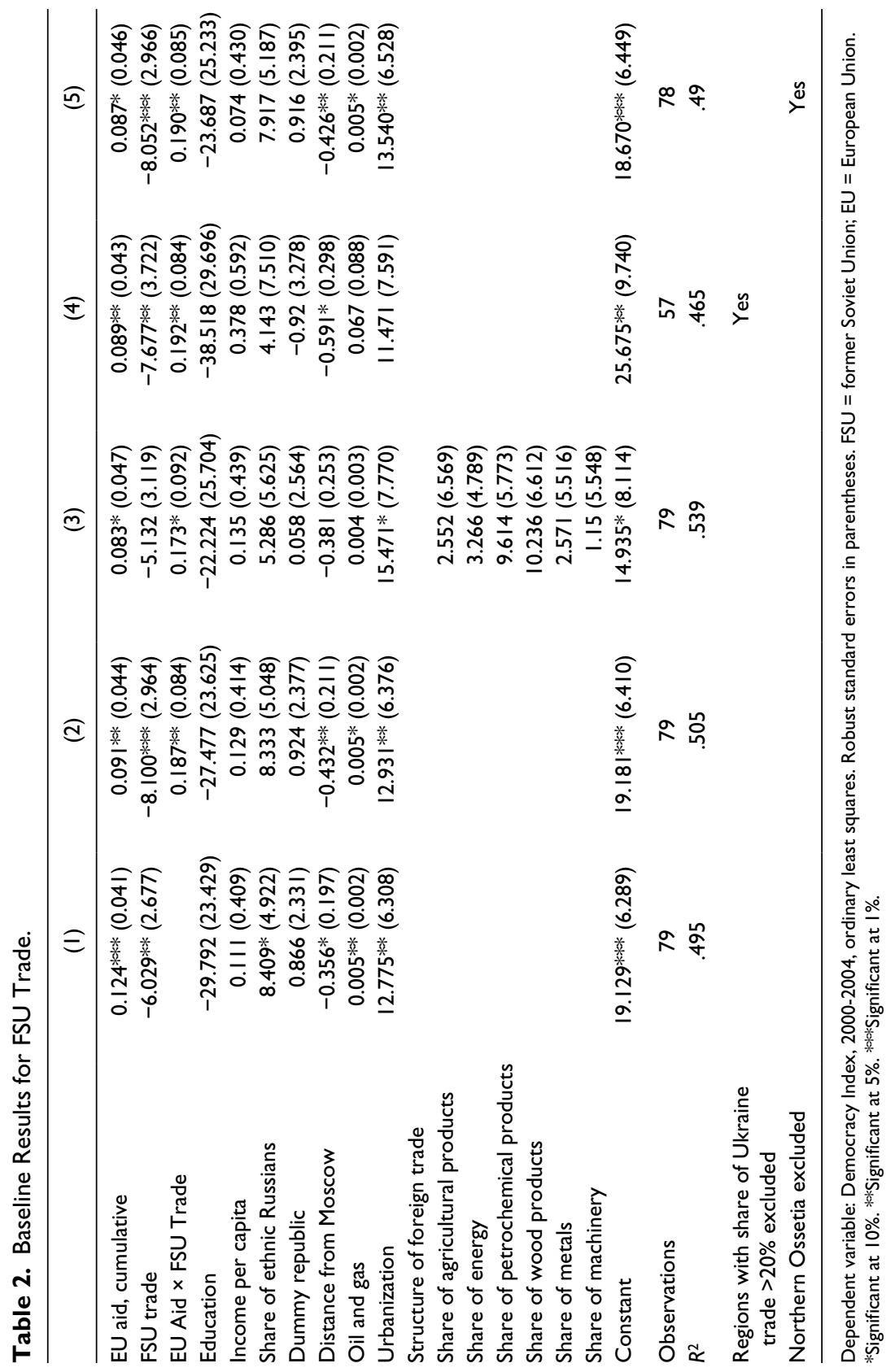




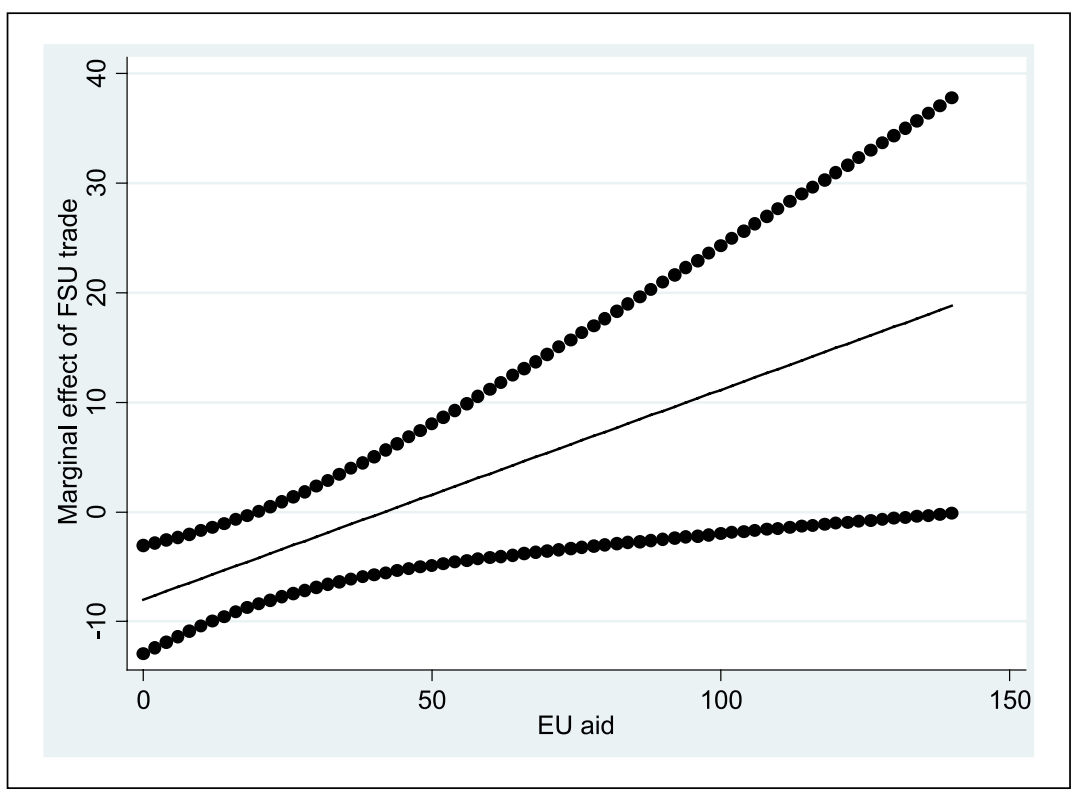

Figure I. Marginal effects of FSU trade on democracy in Russia's regions conditional on EU aid, Model 2, Table 2. FSU = former Soviet Union.

of inter-elite contacts and elite capture of trade. Unfortunately, Russian official statistical compilations do not report the industrial breakdown of FSU and non-FSU trade; but, information on the industrial breakdown of trade volumes in general is available. We are, therefore, able to control for the shares of various industries in the overall structure of trade. The results (Model 3) remain robust.

Model 4 engages with a more important problem. Our analysis is based on the premise that trade with FSU states can be seen as a proxy for authoritarian diffusion. The political regimes of FSU states are heterogeneous, however. Although many were consolidated autocracies during the period of our investigation, some could have qualified as having more competitive regimes, though none would be accurately described as a consolidated democracy. The most obvious examples in this range of cases are Ukraine and Moldova, where political competition had been at a much higher level than in Belarus or in authoritarian Central Asian states such as Uzbekistan or Kazakhstan. Ukraine, though, in this period was ruled by Leonid Kuchma who had been criticized for promoting autocratic tendencies (Way, 2005). Georgia could have been added to 
this group as well from 2003, after the Rose Revolution. Armenia is also occasionally considered to be a country featuring relatively more advanced levels of democracy, particularly when one compares it with Central Asia's autocracies such as Uzbekistan or Kazakhstan. Unlike Georgia, Moldova, and Ukraine, however, because of a record of low political elite turnover, it exhibits more similarities to the hegemonic authoritarian model established in Russia, Belarus, and some other post-Soviet states (Furman, 2010). ${ }^{13}$ Because our main argument rests on the fact that FSU trade can promote authoritarian diffusion, we need to isolate the effect of trade with consolidated autocracies-Azerbaijan and the authoritarian states of Central Asia. ${ }^{14}$

The Russian federal statistics agency does not provide country breakdowns for regional trade data; it only reports the measure of the difference between post-Soviet trade and trade with other countries. However, country breakdowns for trade may be obtained from other sources. Some regional statistical bureaus publish these data. For some of Russia's regions, this information may be available from the offices of the Federal Customs Service, though the reporting standards appear to vary by federal district. Some information may be also obtained from occasional reports published by regional governments and from scholarly publications. Unfortunately, this information is collected in a very unsystematic manner. There is typically no consistent time series data. Some regions do not provide any information at all. Furthermore, frequently, regions list only their main trade partners, while failing to report other trade partners. Based on the heterogeneous sources available, we collected data on the share of regional trade with Ukraine in the total trade turnover of regions (exports plus imports). Ukraine is the largest post-Soviet country and has been among Russia's key trade partners, at least, until the recent Russia-Ukraine conflict. The data are reported in Supplementary Appendix IV and are, to our knowledge, the first systematic attempt to gather such regional trade data for Russia's regions. ${ }^{15}$

We could potentially employ two alternative strategies in utilizing these data. Because the Ukraine trade data come from various sources and are for different time periods, it may be difficult to accurately estimate the share of post-Soviet trade with Ukraine - we may end up subtracting two incomparable variables from each other. Hence, first, we can simply drop regions with a record of large trade volumes with Ukraine and check whether our results still hold. If trade with Ukraine is modest enough, it should not have a major impact on regional regimes. For this purpose, we estimate our model (Model 4) for all of Russia's regions, in which the trade share of Ukraine is below $20 \%$. The results for our main variable FSU trade hold, suggesting that they are driven by countries others than Ukraine. In Supplementary Appendix II, we also employ the-imperfect—alternative strategy, whereby we control 
for the share of trade with Ukraine. Again, the main findings reported above remain robust after isolating the impact of trade with Ukraine.

The three other trade partners that we singled out as having comparatively more democratic political regimes, namely, Georgia, Armenia, and Moldova, are less problematic for us than is Ukraine in terms of data analysis. In the 2000-2004 period covered in our study, Moldova was in an extremely poor economic shape; not a single Russian region reported substantial trade volumes with this country. The same applies to Armenia. Both countries, unlike Ukraine or Georgia, also lack common borders with Russia. Georgia, which does share borders with Russia, also remained an insignificant trade partner, even for neighboring Russia's regions. For instance, in Stavropol krai, in 2000 to 2004, the share of trade with Georgia in the overall regional trade volume was a mere $8.1 \%$. There is, however, one region that constitutes an exception: Northern Ossetia reported Georgia as a predominant trade partner. This is due to the republic's geographic location: It is convenient to cross the Caucasian Mountains separating Russia from Georgia at the North OssetianGeorgian border. The trade statistics, however, are largely driven by trade flows that go via the un-recognized break-away entity of South Ossetia. Before the 2008 Russo-Georgia War, South Ossetia functioned as a large semi-formal trade hub, with its large Ergneti wholesale market serving as "the most flourishing trading entrepôt in the Caucasus" (de Waal, 2010, p. 199); most likely, in the data we have captured the semi-formal aspect of trade. In Model 5, we drop Northern Ossetia, but our results still hold. Thus, we have reasons to believe that the authoritarian diffusion effect that we report is driven in particular by trade with non-democratic post-Soviet countries, especially Azerbaijan and Central Asian states.

In Supplementary Appendix II, we report results with controls for regional trade with another important authoritarian external trade partner, China. We rely on the same approach to create this variable as we did for Ukraine. Specifically, we screened all the publicly available regional statistical compilations, customs services reports, and regional government data. We thereby obtain unique and important data that, to our knowledge, has not been gathered and analyzed by other scholars. China plays an important role in the trade relations of some of Russia's regions: Thus, more than $75 \%$ of trade of the Far Eastern Amur oblast and Tyva is with China. Regional governors have an impact on trade with the Asian neighbor in that, for instance, they often lobby for the selection of their regions to house customs offices and infrastructure such as bridges and roads, thereby "channeling" trade with China to their regions; in some cases, governors also have strong personal business ties with China. ${ }^{16}$ At the same time, trade with China is not rooted in long-term historical ties comparable with those connecting Russia to FSU 
states. In many cases, regional trade links with China started developing only after the collapse of the Soviet Union. Russia's federal authorities may also impose stricter monitoring of trade flows with China than they would with regard to trade with FSU states for security or other reasons related to Russia's foreign policy in its Asian neighborhood. These factors might explain why trade with China does not have a significant impact on regional democracy in our analysis. Our main results remain robust when we control for this variable.

\section{Geographical Measure of Authoritarian Diffusion}

We also employ a different variable that captures potential authoritarian diffusion effects in the post-Soviet space and that is associated with geographic location of Russia's regions. For this purpose, we employ a dummy variable for regions located at the borders to FSU states as our explanatory variable. It is plausible to hypothesize that the diffusion effect is particularly strong in regions adjacent to other post-Soviet countries. Two channels could in this case contribute to the diffusion effect. First, there may be intensive microlevel interactions, for instance, involving Soviet-era diasporas, as well as small cross-border movements of goods and people, which contribute to the diffusion of norms and values. Second, political elites in border regions may engage in more active interactions with elites in neighboring post-Soviet states than would be the case with more distant states. Many regional economic issues could be only resolved through cooperation with neighboring states/regions, as would be the case with the maintenance of Soviet-era shared infrastructure or environmental issues. Furthermore, the period of our investigation is characterized by active and institutionalized cross-border cooperation, which had been partly supported by the federal government (Golunov, 2005).

Empirically, we observe that border regions trade with FSU states much more than do the non-border regions: The average share of FSU trade in the border regions is $31 \%$, as compared with $13 \%$ in the rest of the sample, and the difference is statistically significant. However, these patterns notwithstanding, the effect of geographic location on the level of democracy in Russia's regions is strikingly different from that of trade. Table 3 replicates our regressions for this variable, and we observe no significant results for either the FSU border trade dummy variable or for the interaction term with EU aid. In Table 3, we report the results of models that contain further modifications: In line with the discussion above, we create a dummy variable for regions bordering an FSU country with a consolidated authoritarian regime (Belarus, Kazakhstan, and Azerbaijan), but still find no significant border 


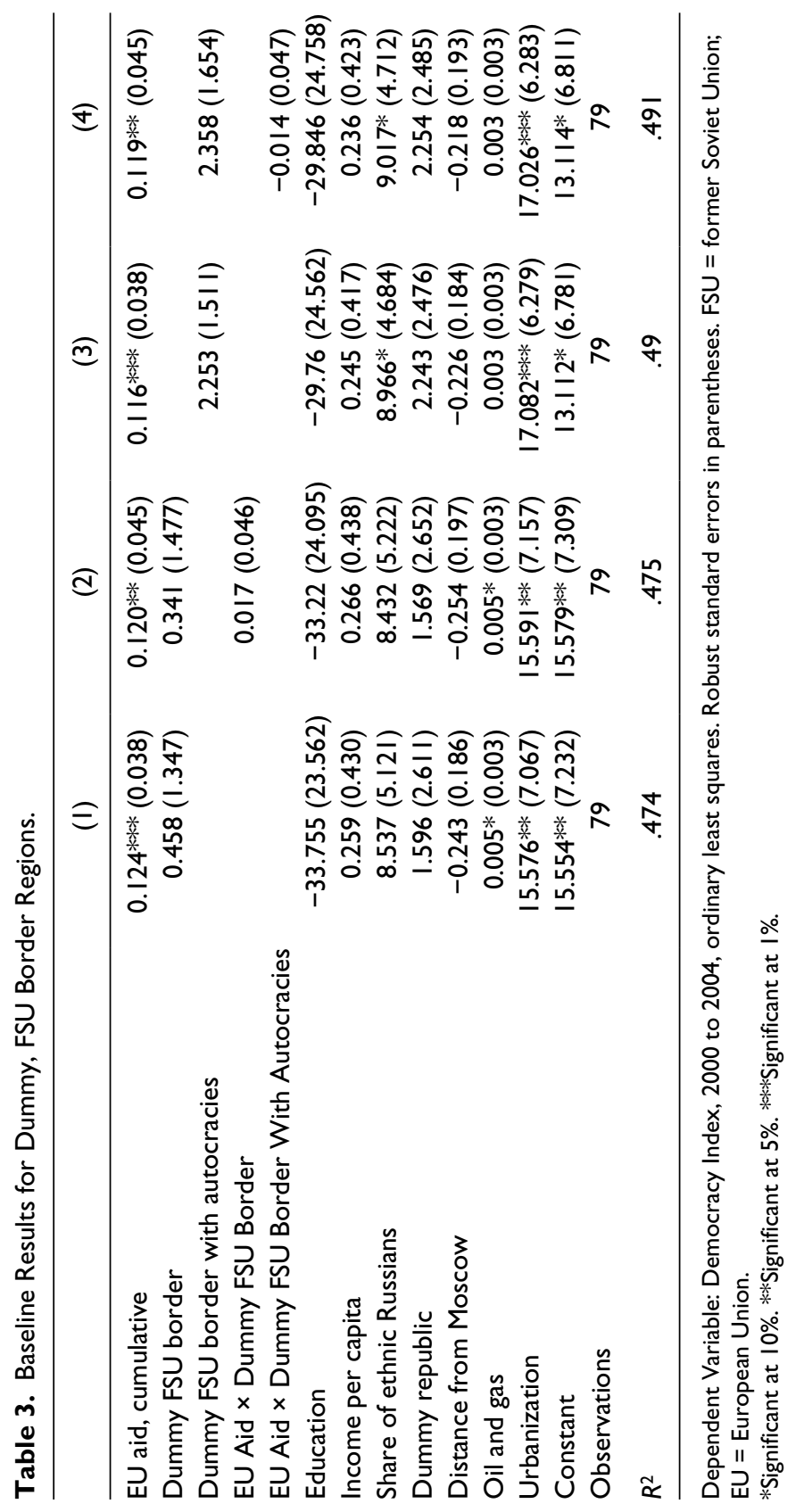


effect. This result clearly confirms the importance of the trade channel of authoritarian diffusion. In fact, although on average, border regions trade more with FSU countries than those in the rest of the sample, there is still substantial heterogeneity in border region trade volumes with neighboring states. Specifically, the range of trade share with all post-Soviet countries in overall regional trade volumes for this group goes from 1\% for Ingushetia and $3 \%$ for Pskov to $68 \%$ for Altai Krai; most likely, it is this variation that determines our results.

\section{Robustness Tests}

We perform a number of additional empirical tests, which we report in Supplementary Appendix III. Here, we highlight the most important findings. First, we look at the effects of our key variables for individual dimensions of the democracy index. We observe significant effects of the interaction term EU aid and FSU trade with regard to five dimensions of the democracy index: economic liberalization, political pluralism, elite composition, civil society, and municipal autonomy. The latter three dimensions may be particularly important for understanding the specific mechanisms through which EU aid might help counteract the effects of authoritarian diffusion. Hypothetically, EU aid can be associated with two effects: It may provide regional actors with additional sources of financing and support and it may enable the socialization of regional politicians in EU democratic values. The first dimension of EU assistance may be particularly relevant for civil society development. At the same time, by socializing regional elites, the EU may encourage them to be more inclined to tolerate regional intra-elite pluralism. Likewise, given the EU's focus on democracy, we would expect regional administrations participating in EU aid projects to be more willing to accept municipal autonomy.

These conjectures are corroborated in further robustness checks. Instead of employing the volume of EU aid measure, we employ the alternative measure of number of EU-funded projects carried out in the regions. ${ }^{17}$ In particular, we look at the number of projects that the EU implemented in a particular region with the participation of different types of actors, namely, NGOs, regional governments, municipal authorities, and federal authorities. The EU's moderating effect is associated with two types of projects: those involving NGOs and those with regional governments as key local partners. Projects involving federal and local governments do not appear to have the same effect. The results pertaining to projects featuring NGOs as key local partners are in line with the hypothetical, civil society channel of EU influence noted above. The effect of projects involving regional governments as key local 
partners is also in line with the elite socialization and circulation processes discussed above. The result with respect to municipalities is somewhat surprising, but may be explicable given the role that regional governors - who in many regions tend to serve as gatekeepers when it comes to authorizing political or economic activity (Golosov, 2011; Hale, 2015; Kynev, 2006; Reuter \& Remington, 2009; Sharafutdinova, 2011) — may play in authorizing and monitoring EU-funded municipal projects.

Finally, we also estimate the regressions for individual components of the democracy index that may be particularly relevant for the purposes of our study (civil society, municipal autonomy, and elite composition) and specific types of EU projects. In analyzing the civil society dimension of aid, we observe that EU involvement weakens the negative effects of FSU trade in projects involving NGOs, that is, projects that directly target civil society actors; and regional governments - in the latter case the EU may affect the environment for the development of civil society. For the dimensions of elite composition and municipal autonomy, all types of EU projects appear to be relevant, except those that feature local governments as key project partners. For the municipal autonomy dimension, we observe a direct and positive effect of EU projects involving local governments as key local partners. The likely channel of influence of EU aid might be through the empowering and training of local administrations and municipal officials; however, EU aid appears to limit the negative effects of FSU trade only in projects involving federal and regional governments and NGOs as key implementing partners. It may be the case that FSU trade adversely affects the development of local autonomy precisely because of the role it plays as a power tool in the hands of regional governments: Regional administrations, controlling access to FSU trade, can use it to limit the power of municipalities as well. Because in many post-Soviet states with which Russian regions trade, the municipal level of authority is substantially weaker than in Russia, mutual learning again might play an important role. EU involvement, however, appears to weaken the above negative effect of FSU trade on regional democracy.

\section{Discussion}

The preceding analysis has uncovered patterns of authoritarian diffusion in Russia's regions, conditioned by trade with post-Soviet states. We also analyzed the democratic impacts of EU aid. In line with earlier scholarship, we find that EU aid has a significant democratizing effect on regional regimes. What is novel in our analysis is that we establish that EU has the potential to counter regional authoritarianism that may be reinforced through trade with post-Soviet partners. We also identify some potential channels of the 
diffusion of authoritarian and democratic influences on regional democratic institutions and practices. We are able to do so because we disaggregate our regional democracy score into the various sub-indicators, and because we possess data on implementing partners for EU projects. In particular, we find that EU support for regional civil society actors might create conditions conducive to the development of checks on regional authoritarian trends. EU aid might also have the effect of socializing regional governors and other officials in ways that serve to increase regional pluralism. These effects in turn appear to mitigate the negative impact of FSU trade on regional democracy uncovered in our study.

Our analysis also suggests directions for future research. To our knowledge, the data on EU aid employed in the study constitute the most refined measures on EU engagement in the post-Soviet region that are available. Most scholars working with EU aid data-as indeed those analyzing global aid flows - employ national-level aggregates of volumes of aid allocated without distinguishing between implementing partners or disaggregating aid data at the level of sub-national regions. Obtaining sub-national data capturing authoritarian diffusion processes presents even greater challenges. Authoritarian states are known to be more secretive than democracies and any officially published data are bound to be unreliable. For instance, it is well known that Russia has been allocating vast amounts of funding to NGOs, media outlets, and religious groups in post-Soviet states as part of its "soft power" agenda. There are, however, no systematic data on Russian or other regional autocracies' targeted activities of this kind that would be similar in scope to the EU data employed in the study. We are aware that our FSU trade data are at best an imperfect proxy for the "spontaneous" authoritarian diffusion processes analyzed in this article. Nevertheless, our analysis constitutes an important step in the direction of systematically analyzing authoritarian diffusion processes, in which trade apparently plays a significant role. It complements qualitative analyses that have focused on the efforts of major authoritarian players such as Russia and China to "diffusion proof" (Koesel \& Bunce, 2013) against democracy, or case studies of authoritarian socialization processes (Allison, 2008; Collins, 2009). Furthermore, in what is different from other studies of authoritarian diffusion, our analysis shines the spotlight on the regional authoritarian effects-through-trade of lesser regional autocracies such as Central Asian dictatorships and Azerbaijan. Analyzing authoritarian diffusion processes employing alternative proxies of autocratic diffusion, and more precisely ascertaining how major and minor authoritarian players might influence regime dynamics in other states and regions, is an agenda for future research. 


\section{Acknowledgments}

The authors are grateful to the editors and the three anonymous reviewers for their very useful comments and suggestions for improving the article. Anastassia Obydenkova presented the paper at the fellows' writing group workshop titled "Mobility, Boundaries, and the Production of Power in Eurasia" at the Davis Center for Russian and Eurasian Studies of Harvard University, and is grateful to colleagues at the Davis Center of Harvard University for their feedback and comments on the article. Any errors are of course solely those of the authors.

\section{Declaration of Conflicting Interests}

The author(s) declared no potential conflicts of interest with respect to the research, authorship, and/or publication of this article.

\section{Funding}

The author(s) disclosed receipt of the following financial support for the research, authorship, and/or publication of this article: Tomila Lankina acknowledges the support and generous funding from the London School of Economics' (LSE) International Relations Department and the LSE Suntory and Toyota International Centers for Economics and Related Disciplines (STICERD) for this research; she also thanks the British Academy for awarding the Mid-Career Fellowship that supported part of the research for this project. Alexander Libman appreciates the generous financial support from the International Center for the Study of Institutions and Development of the National Research University Higher School of Economics in Moscow. His research was conducted within the framework of the Basic Research Program at the National Research University Higher School of Economics (HSE) and supported within the framework of a subsidy granted to the HSE by the government of the Russian Federation for the implementation of the Global Competitiveness Program. Anastassia Obydenkova thanks the Davis Center for Russian and Eurasian Studies at Harvard University for generous funding and intellectual support provided for the implementation of this project. Anastassia V. Obydenkova also acknowledges the support provided for the research presented in this paper by The Laboratory for Applied Studies of Institutions and Social Capital of the Institute for Institutional Studies of the National Research University Higher School of Economics, Moscow, Russia.

\section{Notes}

1. See for instance, a European Union (EU) Press Release on the aims and objectives of the Technical Assistance to the Commonwealth of Independent States (TACIS) program: http://europa.eu/rapid/press-release_MEMO-92-54_en.htm.

2. For a detailed discussion of the aims and objectives of EU aid provision to Russia, see Lankina (2005) and Lankina and Getachew (2006).

3. Trade structure as of 2013; in 2014 to 2015, trade between Ukraine and Russia declined dramatically. 
4. Petrov and Titkov are currently affiliated with the Social Sciences Faculty of the Higher School of Economics in Moscow. Details on the sub-indicators of the index are provided in Supplementary Appendix IV.

5. The strongest correlations are observed for participation in federal elections; and regional electoral misconduct. Data and discussion of the indices are available from Sotsial'nyy atlas rossiyskikh regionov: Integral'nye indeksy http://atlas. socpol.ru/indexes/index_democr.shtml\#methods.

6. Karelia, though, is a notable exception to this trend.

7. The index also includes a measure for municipal independence, as well as subindicators of economic liberalization and corruption. When we recalculate the index without the sub-indicators of economic liberalization and corruption, we obtain results similar to those obtained in the baseline estimation.

8. This time frame is most appropriate for our analysis because it precedes Vladimir Putin's major re-centralization drive - the abolishment of gubernatorial elections in 2004, centralist municipal reforms, and other initiatives that had the effect of undermining, albeit short of completely obliterating, political pluralism in the hitherto more democratic regions. Available evidence suggests, however, that regional political regime variations, which emerged during the 1990s, often persisted over the period covered in our study (Petrov \& Titkov, 2013).

9. Because of strong Soviet-era technological complementarities, post-Soviet businesses are frequently unable to replace their Soviet-era trade partners with those from other countries and continue production without supply or demand from the former Soviet Union (FSU).

10. In the robustness checks reported in the Supplementary Appendix I, we also add a number of further variables, which do not influence our main results.

11. We include Chukotka, which is the only autonomous region that has a status corresponding to an oblast.

12. Supplementary Appendix IV also reports the values of our key variables for all regions in the sample.

13. Another post-Soviet country, Kyrgyzstan, experienced a "color revolution" in 2005, that is, outside the period covered in our analysis. Supplementary Appendix $\mathrm{V}$ reports the average Freedom House and Polity IV scores of post-Soviet countries during the period of our investigation. In both the data sources, Armenia, Moldova, Georgia, and Ukraine feature as former USSR states (excluding the Baltic states) with highest democracy scores.

14. Hypothetically, an attractive option would have been to explore the relative level of democracy in an FSU country compared with the Russian region it trades with. However, our regional democracy score was developed as a comparative measure of democracy in Russia's regions, that is, we may not directly match it with a score for cross-country comparisons, for instance, with a Freedom House score; the "most democratic" Russian region is certainly less democratic than an average EU member state. Furthermore, as Gervasoni (2010) points out, subnational regimes are also conceptually different from national regimes: They may resort to different mechanisms of societal control, for instance, leveraging 
national fiscal transfers; they also follow different developmental logics, so direct comparisons between sub-national regimes and national regimes, again, could be misleading.

15. Supplementary Appendix II also provides detailed information on how the data set was compiled.

16. Author interview with a Russian expert on the economy of the Far East, conducted online on September 28, 2015.

17. EU projects are often low budget, but may nevertheless make a substantial difference in resource-poor regional contexts as when, for instance, computer and broadband resources are provided to a financially struggling non-governmental organization (NGO).

\section{References}

Ademmer, E., \& Börzel, T. A. (2013). Migration, energy and good governance in the EU's eastern neighbourhood. Europe-Asia Studies, 65, 581-608.

Allen, M., \& Gershman, C. (2006). The assault on democracy assistance. Journal of Democracy, 17(2), 36-51.

Allison, R. (2008). Virtual regionalism, regional structures and regime security in Central Asia. Central Asian Survey, 27, 185-202.

Allison, R. (2013). Russia, the West, and military intervention. Oxford, UK: Oxford University Press.

Ambrosio, T. (2007). Insulating Russia from a colour revolution: How the Kremlin resists regional democratic trends. Democratization, 14, 232-252.

Ambrosio, T. (2008). Catching the "Shanghai spirit": How the Shanghai Cooperation Organization promotes authoritarian norms in Central Asia. Europe-Asia Studies, 60(8), 13-21.

Ambrosio, T. (2010). Constructing a framework of authoritarian diffusion: Concepts, dynamics, and future research. International Studies Perspectives, 11, 375-392.

Beissinger, M. R. (2007). Structure and example in modular political phenomena: The diffusion of bulldozer/rose/orange/tulip revolutions. Perspectives on Politics, 4, 259-276.

Bollen, K. (1993). Liberal democracy: Validity and method factors in cross-national measures. American Journal of Political Science, 37, 1207-1230.

Brinks, D., \& Coppedge, M. (2006). Diffusion is no illusion: Neighbor emulation in the third wave of democracy. Comparative Political Studies, 39, 463-489.

Brunell, P. (2006, November). Promoting democracy backwards (Working Paper No. 28). Madrid, Spain: Fundación para las Relaciones Internacionales y el Diálogo Exterior.

Bunce, V., \& Wolchik, S. L. (2011). Defeating authoritarian leaders in postcommunist countries. New York, NY: Cambridge University Press.

Cameron, D. R., \& Orenstein, M. A. (2012). Post-Soviet authoritarianism: The influence of Russia in its "near abroad." Post-Soviet Affairs, 28, 1-44.

Carothers, T. (2006, March/April). The backlash against democracy promotion. Foreign Affairs, 85(2), 55-68. 
Collins, K. (2009). Economic and security regionalism among patrimonial authoritarian regimes: The case of Central Asia. Europe-Asia Studies, 61, 249-281.

Darden, K. A. (2010). Economic liberalism and its rivals: The formation of international institutions among the post-Soviet states. New York, NY: Cambridge University Press.

Deutsch, K. W. (1954). Political community at the international level: Problems of definition and measurement. Garden City, NY: Doubleday.

de Waal, T. D. (2010). The Caucasus: An introduction. Oxford, UK: Oxford University Press.

Diamond, L. (2008, March/April). The democratic rollback: The resurgence of the predatory state. Foreign Affairs, 87(2), 36-48.

Dimitrova, A., \& Pridham, G. (2004). International actors and democracy promotion in central and eastern Europe: The integration model and its limits. Democratization, 11(5), 91-112.

Elkins, Z., \& Simmons, B. (2005). On waves, clusters, and diffusion: A conceptual framework. The ANNALS of the American Academy of Political and Social Science, 598, 33-51.

Finkel, E., \& Brudny, Y. M. (2012a). No more colour! Authoritarian regimes and colour revolutions in Eurasia. Democratization, 19, 1-14.

Finkel, E., \& Brudny, Y. M. (2012b). Russia and the colour revolutions. Democratization, 19, 15-36.

Fordham, B. O., \& Asal, V. (2007). Billiard balls or snowflakes? Major power prestige and the international diffusion of institutions and practices. International Studies Quarterly, 51, 31-52.

Furman, D. (2010). Dvizheniye po spirali: Politicheskaya sistema Rossii v ryadu drugikh sistem [Spiral motion: The Russian political system alongside other political systems]. Moscow, Russia: Ves' Mir.

Gel'man, V., \& Lankina, T. (2008). Authoritarian versus democratic diffusions: Explaining institutional choices in Russia's local government. Post-Soviet Affairs, 24, 40-62.

Gel'man, V., \& Ross, C. (Eds.). (2010). The politics of sub-national authoritarianism in Russia. Farnham, UK: Ashgate.

Gel'man, V., Ryzhenkov, S., Brie, M., Ovchinnikov, B., \& Semenov, I. (2003). Making and breaking democratic transitions: The comparative politics of Russia's regions. Lanham, MD: Rowman \& Littlefield.

Gervasoni, C. (2010). A rentier theory of subnational regimes: Fiscal federalism, democracy, and authoritarianism in the argentine provinces. World Politics, 62, 302-340.

Gleditsch, K. S., \& Ward, M. D. (2006). Diffusion and the international context of democratization. International Organization, 60, 911-933.

Golosov, G. (2011). The regional roots of electoral authoritarianism in Russia. Europe-Asia Studies, 63, 623-639.

Golunov, S. (2005). Rossiysko-Kazakhstanskaya granitsa: Problemy bezopasnosti i mezhdunarodnogo sotrudnichestva [The Russia-Kazakhstan border: Problems of security and international cooperation]. Volgograd, Russia: Volgograd State University. 
Hale, H. E. (2006). Why not parties in Russia? Democracy, federalism, and the state. Cambridge, UK: Cambridge University Press.

Hale, H. E. (2007). Correlates of clientelism: Political economy, politicized ethnicity, and post-communist transition. In H. Kitschelt \& S. I. Wilkinson (Eds.), Patrons, clients and policies: Patterns of democratic accountability and political competition (pp. 227-250). New York, NY: Cambridge University Press.

Hale, H. E. (2015). Patronal politics: Eurasian regime dynamics in comparative perspective. New York, NY: Cambridge University Press.

Kelley, J. (2006). New wine in old wineskins: Promoting political reforms through the new European neighbourhood policy. Journal of Common Market Studies, 44, 29-55.

Koesel, K. J., \& Bunce, V. J. (2013). Diffusion-proofing: Russian and Chinese responses to waves of popular mobilizations against authoritarian rulers. Perspectives on Politics, 11, 753-768.

Kopstein, J. S., \& Reilly, D. A. (2000). Geographic diffusion and the transformation of the postcommunist world. World Politics, 53, 1-37.

Korosteleva, E. A., Natorski, M., \& Simão, L. (2013). The eastern dimension of the European neighbourhood policy: Practices, instruments and social structures. East European Politics, 29, 257-272.

Kynev, A. (2006). Izbiratel'naya reforma Vladimira Putina i regional'nyye vybory [Vladimir Putin's electoral reform and regional elections]. Neprikosnovennyy zapas, 6(50), 117-129.

Langbein, J., \& Börzel, T. A. (2013). Introduction: Explaining policy change in the European Union's eastern neighbourhood. Europe-Asia Studies, 65, 571-580.

Lankina, T. (2005). Explaining European Union aid to Russia. Post-Soviet Affairs, 21, 309-334.

Lankina, T. (2009). Regional developments in Russia: Territorial fragmentation in a consolidating authoritarian state. Social Research, 76, 225-256.

Lankina, T., \& Getachew, L. (2012). Mission or empire, word or sword? The human capital legacy in post-colonial democratic development. American Journal of Political Science, 56, 465-483.

Lankina, T., Libman, A., \& Obydenkova, A. (2016). Appropriation and subversion: Pre-communist literacy, communist party saturation, and post-communist democratic outcomes. World Politics, 68(2), 229-274.

Lankina, T., \& Niemczyk, K. (2015). What Putin gets about soft power. In D. Cadier \& M. Light (Eds.), Russia's foreign policy (pp. 97-113). Basingstoke, UK: Palgrave Macmillan.

Lankina, T. V., \& Getachew, L. (2006). A geographic incremental theory of democratization: Territory, aid, and democracy in postcommunist regions. World Politics, $58,536-582$.

Lankina, T. V., \& Getachew, L. (2008). The virtuous circles of western exposure in Russian regions: A case for micro-polity analysis of democratic change. Journal of Communist Studies and Transition Politics, 24, 338-364.

Lankina, T. V., Hudalla, A., \& Wollmann, H. (2008). Local governance in central and eastern Europe: Comparing performance in the Czech republic, Hungary, Poland and Russia. Basingstoke, UK: Palgrave MacMillan. 
Levitsky, S., \& Way, L. A. (2006). Linkage versus leverage. Comparative Politics, $38,379-400$.

Levitsky, S., \& Way, L. A. (2010). Competitive authoritarianism: Hybrid regimes after the cold war. New York, NY: Cambridge University Press.

Libman, A., \& Obydenkova, A. (2014). International trade as a limiting factor in democratization: An analysis of subnational regions in post-communist Russia. Studies in Comparative International Development, 49, 168-196.

Lipset, S. M. (1959). Some social requisites of democracy: Economic development and political legitimacy. American Political Science Review, 53, 69-105.

Lukinova, E., Myagkov, M., \& Ordeshook, P. C. (2011). Metastasised fraud in Russia's 2008 presidential election. Europe-Asia Studies, 63, 603-621.

Matsuzato, K. (2004). Authoritarian transformation in Mid-Volga national republics: An attempt at macro-regionology. Journal of Communist Studies and Transition Politics, 20, 98-123.

McFaul, M., Petrov, N., \& Riabov, A. (2004). Between dictatorship and democracy: Russian post-communist political reform. Washington, DC: Carnegie Endowment for International Peace.

McMann, K. (2006). Economic autonomy and democracy: Hybrid regimes in Russia and Kyrgyzstan. Cambridge, UK: Cambridge University Press.

Moraski, B., \& Reisinger, W. (2014). The diffusion of deference: Regional machine strength and federal election results in Russia. Unpublished manuscript, University of Iowa, Iowa City.

Myagkov, M., Ordeshook, P. C., \& Shakin, D. (2009). The forensics of electoral fraud: Russia and Ukraine. New York, NY: Cambridge University Press.

Obydenkova, A. (2008). Regime transition in the regions of Russia: The freedom of mass media: Transnational impact on sub-national democratization? European Journal of Political Research, 47, 221-246.

Obydenkova, A., \& Libman, A. (2012). The impact of external factors on regime transition: Lessons from the Russian regions. Post-Soviet Affairs, 28, 346-401.

Obydenkova, A., \& Libman, A. (Eds.). (2015a). Autocratic and democratic external influences in post-Soviet Eurasia. Burlington, VT: Ashgate.

Obydenkova, A., \& Libman, A. (2015b). Causes and consequences of democratization: The regions of Russia. London, England: Routledge.

Obydenkova, A., \& Libman, A. (2015c). Understanding the survival of post-communist corruption in contemporary Russia: The influence of historical legacies. Post-Soviet Affairs, 31, 304-338.

Obydenkova, A. V. (2012). Democratization at the grassroots: The European Union's external impact. Democratization, 19, 230-257.

Obydenkova, A., \& Libman, A. (2014). Understanding the foreign policy of autocratic actors: Ideology or pragmatism? Russia and the Tymoshenko trial as a case study. Contemporary Politics, 20, 347-364.

O’Loughlin, J., Ward, M. D., Lofdahl, C. L., Cohen, J. S., Brown, D. S., Reilly, D., \& Shin, M. (1998). The diffusion of democracy, 1946-1994. Annals of the Association of American Geographers, 88, 545-574. 
Panov, P., \& Ross, C. (2013). Sub-national elections in Russia: Variations in United Russia's domination of regional assemblies. Europe-Asia Studies, 65, 737-752.

Petrov, N., \& Titkov, A. (2013). Reiting demokratichnosti regionov Moskovskogo tsentra Karnegi: 10 let $v$ stroyu [Regional democracy ratings of the Carnegie Moscow Center: Ten years on]. Moscow, Russia: Moscow Carnegie Center.

Pevehouse, J. C. (2002). Democracy from the outside-in? International organizations and democratization. International Organization, 56, 515-549.

Pevehouse, J. C., \& Russett, B. (2006). Democratic international governmental organizations promote peace. International Organization, 60, 969-1000.

Plantan, E. (2014, June). Artful Oppositions and Savvy Dictators: Cycles of Innovative Dissent and Authoritarian Learning. Paper presented at the Comparative Workshop on Mass Protests, London School of Economics and Political Science, London, England.

Pridham, G. (1994). The international dimension of democratisation: Theory, practice, and inter-regional comparisons. In G. Pridham, E. Herring, \& G. Sanford (Eds.), Building democracy? The international dimension of democratisation in eastern Europe (pp. 7-31). New York, NY: St. Martin's Press.

Reddaway, P., \& Orttung, R. W. (Eds.). (2005a). The dynamics of Russian politics: Putin's reform of federal-regional relations (Vol. 1). Lanham, MD: Rowman \& Littlefield.

Reddaway, P., \& Orttung, R. W. (Eds.). (2005b). The dynamics of Russian politics: Putin's reform of federal-regional relations (Vol. 2). Lanham, MD: Rowman \& Littlefield.

Remington, T. F. (2011). The politics of inequality in Russia. New York, NY: Cambridge University Press.

Reuter, O. J., \& Buckley, N. (2015, November 19-22). Performance incentives under autocracy: Evidence from Russia's regions. Paper presented at the Annual Convention of the Association for Slavic, East European and Eurasian Studies, Philadelphia, PA.

Reuter, O. J., \& Remington, T. (2009). Dominant party regimes and the commitment problem: The case of United Russia. Comparative Political Studies, 42, 501-526.

Reuter, O. J., \& Robertson, G. (2012). Subnational appointments in authoritarian regimes: Evidence from Russian gubernatorial appointments. The Journal of Politics, 74, 1023-1037.

Rochlitz, M. (2014, October 22-24). Elections vs. appointments: Comparing incentive patterns for Russian governors under Putin. Paper presented at the Restructuring State and Society in Russia: 14th Annual Aleksanteri Conference, University of Helsinki, Finland.

Ross, M. (2001). Does oil hinder democracy? World Politics, 53, 325-361.

Saikkonen, I. A.-L. (2015). Electoral mobilisation and authoritarian elections: Evidence from post-Soviet Russia. Government \& Opposition. Advance online publication. doi: http://dx.doi.org/10.1017/gov.2015.20 
Schimmelfennig, F. (2002). Introduction. In R. H. Linden (Ed.), Norms and nannies: The impact of international organizations on the central and east European states (pp. 1-29). Lanham, MD: Rowmand \& Littlefield.

Schimmelfennig, F., \& Sedelmeier, U. (Eds.). (2005). The Europeanization of central and eastern Europe. Ithaca, NY: Cornell University Press.

Sharafutdinova, G. (2011). Political consequences of crony capitalism inside Russia. Notre Dame, IN: University of Notre Dame Press.

Silitski, V. (2009). Tools of autocracy. Journal of Democracy, 20(2), 42-46.

Silitski, V. (2010). Contagion deterred: Preemptive authoritarianism in the former Soviet Union. In V. Bunce, M. A. McFaul, \& K. Stoner-Weiss (Eds.), Democracy and authoritarianism in the postcommunist world (pp. 274-299). New York: Cambridge University Press.

Smith, K. E. (2005). The outsiders: The European neighbourhood policy. International Affairs, 81, 757-773.

Stoner-Weiss, K. (1997). Local heroes: The political economy of Russian regional governance. Princeton, NJ: Princeton University Press.

Vachudova, M. (2005). Europe undivided: Democracy, leverage, and integration after communism. Oxford, UK: Oxford University Press.

Vanhanen, T. (2000). A new dataset for measuring democracy, 1810-1998. Journal of Peace Research, 37, 251-265.

Walker, C., \& Kelly, S. (2007). Ruling by law: Ambitions and limits of the 21st century authoritarian model. New York, NY: Freedom House.

Way, L. A. (2005). Kuchma's failed authoritarianism. Journal of Democracy, 16, 131-145.

Way, L. A. (2010). Resistance to contagion: Sources of authoritarian stability in the former Soviet Union. In V. Bunce, M. McFaul, \& K. Stoner-Weiss (Eds.), Democracy and authoritarianism in the postcommunist world (pp. 229-252). New York, NY: Cambridge University Press.

Whitehead, L. (2001). Three international dimensions of democratization. In L. Whitehead (Ed.), The international dimensions of democratization: Europe and the Americas (Expanded ed., pp. 3-25). Oxford, UK: Oxford University Press.

Wilson, A., \& Popescu, N. (2009). Russian and European neighbourhood policies compared. Southeast European and Black Sea Studies, 9, 317-331.

Wilson, J. L. (2009). Coloured revolutions: The view from Moscow and Beijing. Journal of Communist Studies and Transition Politics, 25, 369-395.

Zielonka, J., \& Pravda, A. (Eds.). (2001). Democratic consolidation in eastern Europe: International and transnational factors (Vol. 2). Oxford, UK: Oxford University Press.

\section{Author Biographies}

Tomila Lankina is an associate professor at the International Relations Department of the London School of Economics and Political Science. Her recent research focuses on sub-national democracy and authoritarianism, on protests, and on historical 
patterns of human capital and democratic reproduction in Russia's regions. Recent publications include articles in the American Journal of Political Science, British Journal of Political Science, World Politics, Post-Soviet Affairs, Problems of PostCommunism, Europe-Asia Studies, and other journals. She has also published two books: Governing the Locals: Local Self-Government and Ethnic Mobilization in Russia (Lanham: Rowman \& Littlefield, 2006) and Local Governance in Central and Eastern Europe, co-authored with Anneke Hudalla and Hellmut Wollmann (Palgrave and University of Oxford St. Antony's Series, 2008).

Alexander Libman holds the position of associate at the German Institute for International and Security Affairs in Berlin. His recent research focuses on the politics of authoritarian regimes, sub-national politics, and regionalism in Eurasia. His most recent publications include Causes and Consequences of Democratization: The Regions of Russia (Routledge, with Anastassia Obydenkova), Autocratic and Democratic External Influences in Post-Soviet Eurasia (Ashgate, with Anastassia Obydenkova), Eurasian Integration: Challenges of Transcontinental Regionalism (Palgrave, with Evgeny Vinokurov), Holding-Together Regionalism: Twenty Years of Post-Soviet Integration (Palgrave, with Evgeny Vinokurov), as well as articles in Political Studies, Studies in Comparative International Development, Journal of Common Market Studies, Review of International Political Economy, and Publius.

Anastassia Obydenkova is regional fellow at the Davis Center for Russian and Eurasian Studies at Harvard University. She is also a senior researcher at The Laboratory of Applied Studies of Institutions and Social Capital at the National Research University Higher School of Economics, Moscow, Russia. Her research focuses on the international relations of autocracies, corruption, comparative democratization, international organizations, and the politics of the countries of post-Soviet Eurasia and China. Recent publications include articles in Post-Soviet Affairs, Publius, European Journal of Political Research, Contemporary Politics, Political Studies, Studies in Comparative International Development, Review of International Organizations, and other journals. Her two most recent books, published in 2015, are Causes and Consequences of Democratization: The Regions of Russia, co-authored with Alexander Libman (Routledge: London and New York), and Autocratic and Democratic External Influences in Post-Soviet Eurasia, co-edited with Alexander Libman (Ashgate Publishing: Abington). 